\title{
PENGEMBANGAN PERANGKAT PEMBELAJARAN BERBASIS PENDEKATAN REALISTIK UNTUK MENINGKATKAN KEMAMPUAN PEMECAHAN MASALAH DAN SELF-CONFIDENCE SISWA
}

\author{
Wirdahyani Siregar $^{1}$, Hasratuddin $^{2}$, Edi Syahputra ${ }^{2}$
}

\begin{abstract}
ABSTRAK
Penelitian ini bertujuan untuk mendeskripsikan: 1) Peningkatan kemampuan pemecahan masalah matematis siswa yang diberi pembelajaran dengan menggunakan perangkat yang dikembangkan berbasis pendekatan realistik dibandingkan dengan siswa yang mendapat pembelajaran biasa; 2) Keefektifan perangkat pembelajaran yang dikembangkan melalui pendekatan realistik terhadap kemampuan pemecahan masalah matematis; dan 3) Peningkatan self-confidence siswa yang diberi pembelajaran dengan menggunakan perangkat yang dikembangkan dengan menggunakan pendekatan realistik. Penelitian ini merupakan penelitian pengembangan dengan menggunakan model pengembangan 4-D. Penelitian ini dilakukan melalui dua tahap, yakni tahap pertama validasi perangkat pembelajaran kepada 5 orang validator, dan tahap kedua mengujicobakan perangkat pembelajaran yang dikembangkan menggunakan pendekatan realistik di kelas VIII-3 dan VIII-4 Mts. YAPNI Lubuk Pakam. Dari hasil uji coba I dan uji coba II diperoleh: (1) Terjadi peningkatan nilai rata-rata pada kemampuan pemecahan masalah matematis siswa yang diberi pembelajaran dengan menggunakan perangkat yang dikembangkan berbasis pendekatan realistik dibandingkan dengan siswa yang mendapat pembelajaran biasa, yaitu sebesar 13,89. (2) Perangkat pembelajaran berbasis pendekatan realistik efektif digunakan untuk meningkatkan kemampuan pemecahan masalah matematis; dan (3) Terjadi peningkatan selfconfidence siswa dengan menggunakan perangkat pembelajaran yang dikembangkan dengan menggunakan pendekatan realistik.
\end{abstract}

Kata Kunci: Kemampuan Pemecahan Masalah, Self-Confidence, Model Pengembangan 4-D. Pendekatan Realistik.

\section{PENDAHULUAN}

Pendidikan merupakan suatu proses untuk mengembangkan semua aspek kepribadian manusia yang mencakup pengetahuan, nilai, sikap dan keterampilan. Di era globalisasi saat ini, pendidikan merupakan suatu kebutuhan primer yang memegang peranan penting. Pada saat orang berlomba-lomba untuk mengenyam pendidikan setinggi-tingginya tetapi disisi lain ada sebagian masyarakat Indonesia khususnya anak usia sekolah merasakan putus sekolah baik tingkat dasar maupun ke jenjang yang lebih tinggi lagi. Hal ini disebabkan karena keterbatasan dana pendidikan orangtua karena kesulitan ekonomi, kurangnya fasilitas pendidikan dan karena adanya faktor lingkungan (pergaulan), padahal saat ini pemerintah telah mengadakan program wajib belajar 9 tahun tanpa pungutan biaya. Hal ini tidak sejalan dengan pendidikan nasional yang tertumpu pada Pancasila dan Undang-Undang Dasar 1945 bertujuan untuk mencerdaskan bangsa dan memberantas segala macam kebodohan bangsa Indonesia dan juga tidak sejalan dengan isi UUD 1945 pasal 31 ayat 1-2 yang berbunyi :

1. Setiap warga negara berhak mendapat pendidikan.

2. Setiap warga negara wajib mengikuti pendidikan dasar dan pemerintah wajib membiayai.

Hal ini tidak sesuai juga dengan tren abad 21 saat ini

${ }^{1}$ Corresponding Author: Wirdayahni Siregar

Program Magister Pendidikan Matematika, Universitas Negeri

Medan, Medan, 20221, Indonesia

E-mail: wirdhayani2903@gmail.com

${ }^{2}$ Co-Author: Hasratuddin \& Edi Syahputra

Program Studi Pendidikan Matematika, Universitas Negeri Medan,

Medan, 20221, Indonesia yang mana pendidikan menjadi sangat penting untuk menjamin anak memiliki keterampilan belajar dan berinovasi agar dapat bersaing dengan negara berkembang lainnya. Oleh sebab itu, Hasratuddin (2015:10) menyatakan bahwa masalah yang dihadapi dalam dunia pendidikan Indonesia yaitu mutu pendidikan yang rendah dan sistem pembelajaran sekolah yang kurang memadai. masalah ini perlu perhatian khusus karena apabila tidak ditanggulangi oleh pemerintah berwenang dan juga pendidik maka akan berdampak kepada rusaknya moralitas remaja baik di kota maupun desa, maka dari itu pendidikan sangat berperan penting dalam pembentukan karakter siswa bukan hanya dari segi pengetahuan semata. Peningkatan kualitas pendidikan dapat diwujudkan dengan pengembangan dan pembaharuan dibidang pendidikan.

Salah satu mata pelajaran yang terdapat di dalam pendidikan nasional adalah matematika. Matematika adalah salah satu mata pelajaran yang dipelajari oleh siswa yang di mulai dari Sekolah Dasar, Sekolah Menengah, dan bahkan sampai ke Perguruan Tinggi. Beberapa alasan mengapa matematika penting untuk dipelajari semua siswa.

Melihat pentingnya matematika maka matematika termasuk salah satu mata pelajaran yang menjadi perhatian utama, namun matematika masih merupakan pelajaran yang sulit bagi siswa. Hasil belajar siswa dipengaruhi oleh beberapa faktor. Salah satu faktor diantaranya adalah paradigma guru dalam belajar. Banyak siswa cenderung dilatih untuk melakukan

Pengembangan Perangkat Pembelajaran Berbasis Pendekatan Realistik untuk Meningkatakan Kemampuan Pemecahan Masalah dan Self Confidence Siswa 
perhitungan matematika daripada dididik untuk berpikir matematis. Artinya, dalam proses pembelajaran, guru hanya berfokus untuk melatih daya hitung siswa saja yang mengakibatkan siswa menjadi bosan dan jenuh terhadap matematika yang banyak menggunakan rumus secara abstrak sehingga siswa banyak yang tidak tertarik terhadap pelajaran matematika.

Selain itu, Hasratuddin (2015:37) masih banyak para guru yang menganut paradigma transfer of knowledge dalam pembelajaran, yaitu tidak menuntut aktivitas mental siswa. Bagian terbesar dari matematika yang dipelajari siswa di sekolah tidak diperoleh melalui eksplorasi matematis, tetapi melalui pemberitahuan. Sehingga kemerosotan kemampuan siswa dalam matematika antara lain dikarenakan cara mengajar yang dilakukan guru masih menggunakan pembelajaran yang kurang tepat melalui metode konvensional, lebih menekankan pada latihan mengerjakan soal atau drill. Konsekuensi dari pola pembelajaran konvensional dan latihan mengerjakan soal secara drill mengakibatkan siswa kurang aktif dan kurang memahami konsep maupun nilai-nilai matematis.

Selanjutnya, pada pelaksanaan pembelajaran matematika sering sekali guru mengalami kesulitan dalam menyampaikan materi agar siswa memperoleh konsep secara benar. Oleh karena itu perlu dipikirkan cara penyajian matematika yang membuat siswa terlibat aktif dan merasa senang dalam belajar matematika. Umumnya guru tidak mempersiapkan persiapan yang matang sebelum mengajar. Dalam proses pembelajaran, guruguru tersebut hanya memakai buku seadanya, yaitu memakai buku yang sama dengan buku pegangan siswa.

Dalam pembelajaran, guru juga menyertakan Lembar Kerja Peserta Didik (LKPD), tetapi lembar kerja yang digunakan guru adalah lembar kerja siswa yang di dapat dari pengarang yang bisa di beli di toko buku yang berisikan soal-soal rutin dan terkesan monoton, bukanlah lembar kerja peserta didik yang dirancang guru yang dapat mengukur kemampuan dalam materi dan menarik perhatian siswa. Idealnya, gurulah yang memahami karakteristik siswa, sehingga gurulah yang dapat mengembangkan lembar kerja peserta didik agar sesuai dengan kemampuan yang ingin dicapai.

Sehingga dapat disimpulkan dari hasil observasi dan wawancara dalam penelitian bahwa kurang tuntasnya hasil belajar siswa dipengaruhi oleh kurangnya semangat belajar siswa karena kurang variatif dan efektifnya model/metode/pendekatan yang digunakan guru, kurangnya minat dan motivasi siswa dalam mengikuti pembelajaran, penjelasan materi pelajaran lebih berpusat pada guru sehingga tidak tercipta kondisi keaktifan dari siswa, perhatian siswa tidak fokus, malas-malasan bahkan lebih memilih bermain hp daripada mendengarkan guru .

Tujuan dikembangkannya perangkat pembelajaran adalah untuk menghasilkan sebuah produk yang dapat membantu siswa dalam proses pembelajaran di dalam kelas, dimana produk tersebut dapat mencapai tujuan pembelajaran yang diinginkan terutama dalam meningkatkan kemampuan matematis siswa. Oleh sebab itu, Nieveen (1999:126) menyatakan bahwa perangkat pembelajaran dikatakan baik jika memenuhi aspek kualitas yang meliputi : validitas (validity), kepraktisan (practically) dan keefektifan (effectiveness).

Salah satu inovasi dalam meningkatkan kualitas pendidikan adalah dengan mengembangkan perangkat pembelajaran. Tetapi kenyataannya perangkat pembelajaran hanya digunakan sebatas administrasi dan formalitas untuk kepentingan sekolah saja. Suparno (2002:17) menyatakan bahwa "Sebelum guru mengajar (tahap persiapan) seorang guru diharapkan mempersiapkan bahan yang ingin diajarkan, mempersiapkan alat peraga/praktikum yang akan digunakan, mempersiapkan pernyataan dan arah untuk memancing siswa untuk lebih aktif belajar, mempelajari keadaan siswa, serta mempelajari pengetahuan awal siswa, kesemua ini akan terurai pelaksanaannya di dalam perangkat pembelajaran".

Tetapi pada kenyataannya, guru masih membuat atau menyusun perangkat pembelajaran seperti RPP tidak mencerminkan pernyataan di atas. Guru masih menyusun RPP secara sederhana dan tidak mencerminkan RPP yang baik. Umumnya guru tidak melakukan persiapan yang matang sebelum mengajar. Padahal sebelum melaksanakan pembelajaran, guru hendaknya mempersiapkan bahan yang akan di ajarkan pada siswa pada saat pembelajaran.

Seperti yang diungkapkan Suparno (2002) Sebelum guru mengajar (tahap persiapan) seorang guru diharapkan mempersiapkan bahan yang mau diajarkan, mempersiapkan alat-alat peraga/praktikum yang akan digunakan, mempersiapkan pertanyaan dan arahan untuk memancing siswa aktif belajar, mempelajari keadaan siswa, mengerti kelemahan dan kelebihan siswa, serta mempelajari pengetahuan awal siswa, kesemuannya ini akan terurai pelaksanaannya didalam perangkat pembelajaran.

Maka jelas bahwa perangkat pembelajaran ini sangat penting. Baiknya sebelum guru melaksanakan pembelajaran dikelas, guru mempersiapkan dan merancang perangkat pembelajaran dengan sebaik mungkin demi terlaksanakan pembelajaran yang efektif saat proses belajar mengajar berlangsung. Perangkat pembelajaran perlu dibuat dan dikembangkan oleh guru.

Dengan penyusunan dan pengembangan perangkat pembelajaran yang baik, harapannya mutu pembelajaran, pengembangan profesi, dan mutu lembaga akan lebih baik. Hal ini berarti perangkat pembelajaran yang dikembangkan bukan hanya berguna untuk meningkatkan kemampuan siswa namun berguna bagi guru untuk meningkatkan kualitas mengajarnya dan pengembangan profesi.

Namun kenyataan dilapangan bahwa masih banyak guru yang belum merancang perangkat pembelajaran dengan baik. Sering ditemukan perangkat pembelajaran hanya sebatas "asal buat" untuk kelengkapan administrasi belaka Berdasarkan hasil pengamatan yang telah dilakukan pada MTs. Yapni Lubuk Pakam, RPP yang rancang masih belum sesuai dengan ketentuan kriteria.

Berdasarkan hasil wawancara dari salah satu guru yang mengajar di MTs. YAPNI Lubuk Pakam bahwa

Pengembangan Perangkat Pembelajaran Berbasis Pendekatan Realistik untuk Meningkatakan Kemampuan Pemecahan Masalah dan Self Confidence Siswa 
dalam kegiatan belajar mengajar di kelas selama ini, masih ada siswa yang menampakkan sikap apatis atau menunjukkan sikap tidak ingin tahu terhadap pelajaran matematika tetapi ada sebagian siswa merespon guru saat pembelajaran. Selain itu, menurut salah satu guru matematika di MTs. YAPNI Lubuk Pakam, kesalahan guru yaitu guru malas dalam menerapkan model-model pembelajaran yang ada dan juga belum mengenalkan kemampuan matematis (dalam hal ini kemampuan pemecahan masalah matematis yang sesuai dengan indikator Polya) yang harus dimiliki siswa. Menurut guru tersebut, kemampuan pemecahan masalah matematis siswa di MTs. YAPNI Lubuk Pakam juga masih tergolong rendah.

Kemudian dalam mengerjakan latihan individu pada saat proses pembelajaran yang diberikan guru, hanya sebagian kecil siswa yang mampu menyelesaikan soal dengan menggunakan konsep diketahui, ditanya dalam bentuk tulisan, menggunakan istilah atau notasi matematika, serta menyatakan situasi ke dalam model matematika dengan tepat. Hal ini memberikan informasi bahwa kemampuan siswa saat mengerjakan soal untuk pemecahan masalah mendapatkan nilai rendah.

Selain kemampuan pemecahan masalah, dalam pembelajaran matematika terdapat aspek psikologis yang harus diperhatikan. Menurut Hasratuddin (2015:56) Suatu paradigma baru terhadap pembelajaran matematika yang terjadi melalui suatu kajian penelitian pengembangan adalah menghubungkan belajar dan berpikir serta pengembangkan sikap kepribadian. Sedangkan pendapat lain, Nelissen (2005) mengatakan bahwa pengajaran matematika sekarang ini sudah saatnya berfokus pada keterampilan bepikir dan refleksi belajar, interaksi dan pengembangan dari konsep-konsep berpikir spesifik. Hal ini menjadi dasar dan pertimbangan akan perubahan dalam proses pembelajaran matematika sekolah yang tidak lagi hanya menekankan pada pengembangan ranah kognitif saja.

Salah satu aspek tersebut adalah self-confidence atau kepercayaan diri. Selain faktor guru untuk melihat hasil belajar matematika, maka faktor lain yang mempengaruhi adalah self-confidence (rasa percaya diri) siswa dalam pembelajaran matematika. Rasa percaya diri dalam pembelajaran matematika merupakan keyakinan siswa tentang kompetensi diri dalam matematika dan kemampuan seseorang dalam pembelajaran matematika. Rasa percaya diri siswa dalam pembelajaran matematika penting bagi kesuksesan kinerja matematikanya.

Menurut Lauster (2002:4) kepercayaan diri merupakan suatu sikap atau keyakinan atas kemampuan diri sendiri sehingga dalam tindakan-tindakannya tidak terlalu cemas, merasa bebas untuk melakukan hal-hal yang sesuai keinginan dan tanggungjawab atas perbuatannya, sopan dalam berinteraksi dengan orang lain, memiliki dorongan prestasi serta dapat mengenal kelebihan dan kekurangan diri sendiri.

Dengan adanya rasa percaya diri, siswa akan lebih termotivasi dan lebih menyukai untuk belajar matematika. Namun pada kenyataanya self confidence siswa masih tergolong rendah.
Hasil pengamatan pembelajaran di MTs. YAPNI Lubuk Pakam yaitu ketika siswa diberikan pertanyaan/soal oleh guru, siswa menjawab dengan tidak yakin atau ragu-ragu, adanya rasa khawatir tentang respon atau penilaian orang lain terhadap dirinya, yaitu mengenai apa yang disampaikannya dan bagaimana ia menyampaikannya. Menurut Lauster (1978) Ketergantungan terhadap penilaian orang lain ini merupakan salah satu ciri dari orang yang kurang percaya diri.

Kenyataan yang ada di lapangan berdasarkan hasil wawancara dengan guru di MTs. YAPNI menunjukkan bahwa guru matematika jarang memberi perhatian yang proporsional dalam meningkatkan self-confidence siswa. Ketika peneliti menanyakan langsung kepada beberapa siswa kelas VIII, pada saat pembelajaran berlangsung, siswa masih merasa kurang percaya diri untuk mengungkapkan pendapatnya dan pada umumnya hanya akan menjawab soal ketika ditunjuk guru saja. Ketika diberi soal, siswa pada umumnya masih pasif dengan menunggu jawaban dari temannya atau dari guru. Hal ini membuat self-confidence siswa masih rendah.

Menyikapi permasalahan yang terjadi di lapangan selama ini, yaitu dalam proses pembelajaran matematika di sekolah, terutama yang berkaitan dengan pentingnya kemampuan pemecahan masalah dan selfconfidence siswa yang akhirnya mengakibatkan rendahnya hasil belajar siswa. Perlu adanya solusi berupa pendekatan pembelajaran yang dapat mengakomodasi peningkatan kemampuan pemecahan masalah dan self-confidence siswa. Salah satu pendekatan pembelajaran yang berpusat pada peserta didik dan mengaitkan materi matematika dalam kehidupan nyata peserta didik adalah pendekatan realistik. Salah satu model/pendekatan yang tidak pernah diterapkan guru MTs.Yapni dalam pembelajaran adalah Pendekatan Realistik.

Pendekatan realistik dikembangkan oleh Freudenthal pada tahun 1977. Ide utama dari pendekatan ini adalah siswa harus diberi kesempatan untuk menemukan kembali (reinvention) ide dan konsep matematika melalui penjelajahan berbagai situasi dan persoalan dunia nyata (real world) dengan bimbingan orang dewasa dan secara bertahap berkembang menuju kepemahaman matematika.

Dalam pendekatan matematika realistik, masalahmasalah yang bersifat kontekstual atau realistik dijadikan sebagai titik awal dalam pembelajaran, yang kemudian dimanfaatkan oleh siswa dalam melakukan proses matematisasi dan pengembangan model matematika. Melalui masalah yang bersifat kontekstual tersebut, siswa dilatih untuk dapat memecahkan masalah dengan caranya sendiri sekaligus berlatih memahami cara yang digunakan siswa lain.

Pada prinsip ini, siswa diberikan kesempatan untuk menunjukkan kemampuannya dalam memecahkan masalah matematis. Dengan demikian pendekatan realistik memungkinkan digunakan untuk meningkatkan kemampuan pemecahan masalah matematis siswa. Pendekatan ini dipandang sebagai

Pengembangan Perangkat Pembelajaran Berbasis Pendekatan Realistik untuk Meningkatakan Kemampuan Pemecahan Masalah dan Self Confidence Siswa 
pendekatan yang banyak memberikan harapan bagi peningkatan hasil pembelajaran matematika. Jadi, dalam pendekatan realistik masalah realistik digunakan sebagai stimulator utama dalam upaya rekonstruksi pengetahuan peserta didik.

Tarigan (dalam Yosmarniati, dkk., 2014:65) mengatakan, "dalam pembelajaran matematika realistik dimulai dari masalah yang real sehingga siswa dapat terlibat dalam proses pembelajaran secara bermakna. Peran guru terutama sebagai pembimbing dan fasilitator bagi siswa dalam proses rekonstruksi ide dan konsep matematika".

Melalui masalah yang bersifat kontekstual tersebut, siswa dilatih untuk dapat memecahkan masalah dengan caranya sendiri sekaligus berlatih memahami cara yang digunakan siswa lain. Pada prinsip ini, siswa diberikan kesempatan untuk menunjukkan kemampuannya dalam memecahkan masalah matematis. Dengan demikian pendekatan realistik memungkinkan digunakan untuk meningkatkan kemampuan pemecahan masalah matematis siswa.

Berdasarkan hal di atas maka dianggap penting bagi peneliti untuk mengadakan penelitian dengan judul "Pengembangan Perangkat Pembelajaran Berbasis Pendekatan Realistik Untuk Meningkatkan Kemampuan Pemecahan masalah dan Self-Confidence Siswa MTs. YAPNI L ubuk Pakam".

\section{KAJIAN TEORITIS}

\section{Kemampuan Pemecahan Masalah}

Pemecahan masalah merupakan bagian dari kurikulum matematika yang sangaat penting. Hal ini dikarenakan siswa akan memperoleh pengalaman dalam menggunakan pengetahuan serta keterampilan yang dimiliki untuk menyelesaikan soal yang tidak rutin. Menurut Lencher (dalam Wardhani, dkk, 2010 : 15) mendefinisikan pemecahan masalah matematika sebagai proses menerapkan pengetahuan matematika yang telah diperoleh sebelumnya ke dalam situasi baru yang belum dikenal.

NCTM mengemukakan bahwa pemecahan masalah merupakan proses menerapkan pengetahuan yang telah diperoleh sebelumnya pada situasi baru dan berbeda. Selain itu NCTM juga mengungkapkan tujuan pengajaran pemecahan masalah secara umun adalah untuk (1) membangun pengetahuan matematika baru, (2) memecahkan masalah yang muncul dalam matematika dan di dalam konteks-konteks lainnya, (3) menerapkan dan menyesuaikan bermacam strategi yang sesuai untuk memecahkan permasalahan dan (4) memantau dan merefleksikan proses dari pemecahan masalah matematika.

Sedangkan Polya mengartikan pemecahan masalah sebagai satu usaha mencari jalan keluar dari satu kesulitan guna mencapai satu tujuan yang tidak begitu mudah segera untuk dicapai.

Dalam bukunya yang berjudul How to Solve It, Polya mengembangkan empat tahap proses pemecahan masalah, berikut indikator pemecahan masalah :

a. Memahami Masalah b. Merencanakan Penyelesaian Masalah

c. Melaksanakan Rencana Penyelesaian Masalah

d. Pemeriksaan Kembali

Dalam penelitian ini, yang dimaksud dengan kemampuan pemecahan masalah adalah suatu keterampilan pada diri peserta didik agar mampu menggunakan kegiatan matematik untuk memecahkan masalah dalam matematika, masalah dalam ilmu dan masalah dalam kehidupan sehari-hari

\section{Self-Confidence}

Self-confidence atau percaya diri adalah sejauh mana anak mempunyai keyakinan terhadap penilaian anak atas kemampuan anak dan sejauh mana anak bisa merasakan adanya "kepantasan" untuk berhasil.

Menurut Jacinta 2002，Self-confidence adalah sikap positif seorang individu yang merasa memiliki kompetensi atau kemampuan untuk mengembangkan penilaian positif baik terhadap dirinya maupun lingkungan. Menurut Hasan (dalam Iswidharmanjaya, 2004) menyatakan self-confidence adalah percaya akan kemampuan sendiri yang memadai dan menyadari kemampuan yang dimiliki, serta dapat memanfaatkan secara tepat. Berdasarkan dengan aspek-aspek kepercayaan diri, adapun indikator self-confidence menurut Lestari (2015 : 96) :

a. Keyakinan/Percaya diri

b. Bertindak mandiri

c. Memiliki konsep diri yang positif

d. Berani mengungkapkan pendapat

3. Pendekatan Realistik

Salah satu pendekatan pembelajaran yang berpusat pada peserta didik dan mengaitkan materi matematika dalam kehidupan nyata peserta didik adalah pendekatan realistik atau salah satu pendekatan dari Realistic Mathematics Education. Pendekatan realistik pertama kali dikembangkan di Belanda sejak tahun 1971 pada Institute Freudenthal bernama Hans Freudenthal.

Treffers (dalam Heuvel-Panhuizen, 2003:12) menyebutkan dua jenis matematisasi dalam realistic mathematic education yaitu matematisasi horizontal dan vertikal. Matematisasi horizontal berkenaan dengan proses transformasi masalah nyata ke dalam konsep-konsep abstrak (simbol matematika). Melalui proses ini, siswa dengan pengetahuan yang dimilikinya diharapkan dapat mengorganisasikan dan memecahkan masalah yang dihadapi dalam kehidupan nyata. Sementara matematisasi vertikal merupakan proses yang terjadi dalam lingkup simbol matematika itu sendiri. Ada tiga unsur prinsip utama dalam pembelajaran matematika realistik yaitu :

a. Guided reinvention and progresive mathematizing (penemuan terbimbing dan pematematikaan progresif).

b. Didactical phennomenology (fenomena pembelajaran).

c. Self development models (model - model dibangun sendiri).

Proses pembelajaran dengan menggunakan pendekatan realistik adalah proses pembelajaran yang

Pengembangan Perangkat Pembelajaran Berbasis Pendekatan Realistik untuk Meningkatakan Kemampuan Pemecahan Masalah dan Self Confidence Siswa 


\section{PARADIKMA JURNAL PENDIDIKAN MATEMATIKA}

Vol. 13, No. 2, Desember 2020

sesuai dengan karakteristik prinsip-prinsip pembelajaran realistik. Romauli (2013:4) Adapun langkah-langkah kegiatan guru dan siswa dalam kegiatan pendekatan realistik adalah: (a) memahami masalah kontekstual, (b) menyelesaikan masalah kontekstual, (c) membandingkan dan mendiskusikan jawaban, dan (d) menyimpulkan

\section{METODE PENELITIAN}

Penelitian ini merupakan penelitian pengembangan yaitu pengembangan perangkat pembelajaran matematika berbasis Pendekatan Realistik untuk meningkatkan kemampuan pemecahan masalah dan self-confidence. Model pengembangan yang digunakan adalah model pengembangan perangkat pembelajaran matematika yang mengacu pada model 4-D yang dikemukakan oleh Thiagarajan, Semmel dan Semmel (1974:421).

\section{Prosedur dan Rancangan Penelitian}

Penelitian ini dibagi dalam dua tahap, yaitu : (1) Tahap pertama adalah pengembangan perangkat pembelajaran yang meliputi validasi RPP, validasi BG, validasi BS, validasi LKPD dan validasi Tes Kemampuan Pemecahan Masalah Matematis yang dilakukan melalui : (a) Perencanaan dan telaah oleh pakar, (b) ujicoba terbatas dengan subyek penelitian beberapa orang. Hal ini dilakukan untuk melihat kelayakan perangkat pembelajaran yang dikembangkan.; dan (2) Tahap kedua adalah implementasi perangkat pembelajaran yang dianggap sudah layak berdasarkan hasil ujicoba .

Adapun rancangan uji coba yang digunakan dalam penelitian ini adalah one-shot case study atau disebut juga dengan one-group posttest-only design (Setyosari, 2012:174). Rancangan penelitian one-shot case study ini direpresentasikan sebagai berikut:

\begin{tabular}{cc}
\hline Perlakuan & Ies \\
$\mathbf{X}$ & O \\
\hline
\end{tabular}

$\mathrm{X}$ : Perlakuan pembelajaran menggunakan perangkat pembelajaran berbasis pendekatan realistik yang telah dikembangkan.

$\mathrm{O}$ : Tes kemampuan pemecahan masalah matematis dan self-confidence.

Selanjutnya data hasil uji coba dianalisis dan direvisi untuk mendapatkan perangkat pembelajaran berbasis pendekatan realistik yang final.

\section{Instrumen Penelitian}

Penelitian ini menggunakan dua jenis instrumen yaitu intrumen tes dan non tes. Instrumen tes berupa tes kemampuan pemecahan masalah matematis, sedangkan instrumen non tes berupa angket untuk mengukur selfconfidence siswa

\section{Uji Coba Instrumen}

Sebelum instrumen penelitian digunakan, terlebih dahulu di validasi isi semua perangkat tes dan dianalisis oleh tiga dosen dan dua guru mata pelajaran matematika. Validitas isi ditetapkan berdasarkan kesesuaian antara kisi-kisi soal dengan butir soal.

Setelah dilakukan validasi ahli mengenai instrumen penelitian, selanjutnya instrumen yang validitas isinya memadai diuji cobakan kepada siswa yang berada di luar sampel penelitian. Hal ini dilakukan untuk melihat validitas, reabilitas.

a. Analisis Data Validitas Perangkat Pembelajaran

Untuk melihat kevalidan perangkat pembelajaran digunakan analisis statistik deskriptif berdasarkan ratarata skor dari masing-masing perangkat pembelajaran yang telah divalidasi oleh validator/ahli dalam bidang pendidikan matematika dan direvisi berdasarkan koreksi serta saran para validator/ahli.

\section{b. Angket Self-Confidence}

Untuk mengukur self-confidence digunakan skala self-confidence. Skala self-confidence digunakan untuk mengukur keyakinan siswa terhadap kemampuannya melakukan tindakan-tindakan yang diperlukan dalam menyelesaikan soal yang melibatkan kemampuan pemecahan masalah matematis dengan berhasil.

Tabel 1. Skor Alternatif Skala Self-Confidence

\begin{tabular}{cccc}
\hline \multicolumn{2}{c}{ Pernyataan positif } & \multicolumn{2}{c}{ Pernyataan negatif } \\
\hline $\begin{array}{c}\text { Alternatif } \\
\text { Jawaban }\end{array}$ & Skor & $\begin{array}{c}\text { Alternatif } \\
\text { Jawaban }\end{array}$ & Skor \\
\hline Selalu & 4 & Selalu & 1 \\
\hline Sering & 3 & Sering & 2 \\
\hline Jarang & 2 & Jarang & 3 \\
\hline Tidak Pernah & 1 & Tidak Pernah & 4 \\
\hline \multicolumn{4}{r}{ (Modifikasi Ruseffendi, 2005:135) }
\end{tabular}

\section{HASIL PENELITIAN}

1. Kemampuan Pemecahan Masalah

Keefektifan perangkat pembelajaran yang dikembangkan ditinjau dari beberapa hal, yaitu : $85 \%$ siswa yang mengikuti tes hasil belajar kemampuan pemecahan masalah matematis memperoleh nilai minimal 75 , tercapainya ketuntasan tujuan pembelajaran siswa $75 \%$, serta $80 \%$ siswa memberi respon positif terhadap perangkat pembelajaran yang dikembangkan.

Hasil pada uji coba I didapat bahwa kemampuan pemecahan masalah siswa belum memenuhi indikator keefektifan, dimana hanya $54,05 \%$ yang memperoleh nilai $>75$, hanya $69,01 \%$ tercapainya ketuntasan tujuan pembelajaran, dan dari segi respon positif siswa terhadap perangkat pembelajaran yang dikembangkan sebesar $91,5 \%$. Ini menunjukkan bahwa hasil uji coba I belum efektif untuk siswa. Faktor yang mempengaruhi belum meningkat dan efektifnya uji coba I dikarenakan salah satunya adalah dari internal siswa, dimana siswa belum siap untuk merubah pola belajar mereka selama ini, dimana mereka hanya berpusat kepada guru sebagai pemberi ilmu dan juga kurangnya motivasi yang peneliti sampaikan sehingga mereka belum paham tujuan dari pembelajaran, dan juga kurangnya minat belajar siswa kelas VIII-4 terhadap matematika, mereka selama ini hanya terbiasa mencatat apa yang ada di papan tulis hanya sebagai rutinitas dalam matematika.

Pemberian Tes Hasil Belajar Kemampuan Pemecahan Masalah pada uji coba I dan uji coba II bertujuan untuk mengetahui peningkatan kemampuan pemecahan masalah matematis siswa setelah diberi perlakuan pembelajaran menggunakan perangkat pembelajaran berbasis pendekatan realistik pada materi

Pengembangan Perangkat Pembelajaran Berbasis Pendekatan Realistik untuk Meningkatakan Kemampuan Pemecahan Masalah dan Self Confidence Siswa 
peluang. Berikut disajikan tabel Hasil uji coba I dan uji coba II.

Tabel 2. Peningkatan Kemampuan Pemecahan Masalah Matematis

\begin{tabular}{cccccc}
\multirow{2}{*}{ Uraian } & \multicolumn{5}{c}{ Nilai Rata-rata } \\
\cline { 2 - 4 } & $\begin{array}{c}\text { Ind. } \\
1\end{array}$ & $\begin{array}{c}\text { Ind. } \\
2\end{array}$ & $\begin{array}{c}\text { Ind. } \\
3\end{array}$ & $\begin{array}{c}\text { Ind. } \\
4\end{array}$ & $\begin{array}{c}\text { Klasik } \\
\text { al }\end{array}$ \\
\hline Uji Coba I & $\begin{array}{c}2,0 \\
2\end{array}$ & 0,69 & 2,45 & 1,58 & $\begin{array}{c}54,05 \\
\%\end{array}$ \\
\hline Uji Coba II & $\begin{array}{c}2,3 \\
7\end{array}$ & 0,79 & 2,69 & 2,18 & $\begin{array}{c}86,49 \\
\%\end{array}$ \\
\hline $\begin{array}{c}\text { Peningkata } \\
\text { n }\end{array}$ & $\begin{array}{c}0.3 \\
5\end{array}$ & 0,10 & 0,24 & 0,6 & $\begin{array}{c}32,44 \\
\%\end{array}$ \\
\hline
\end{tabular}

Berdasarkan hasil analisis peningkatan kemampuan pemecahan masalah matematis siswa pada uji coba I dan II menunjukkan bahwa rata-rata kemampuan pemecahan masalah matematis siswa secara klasikal pada uji coba I adalah sebesar $54,05 \%$, kemudian meningkat menjadi $86,49 \%$ pada uji coba II. Dengan demikian, terjadi peningkatan nilai rata-rata kemampuan pemecahan masalah matematis siswa sebesar $32,44 \%$. Rata-rata peningkatan untuk setiap indikator pada kemampuan pemecahan masalah matematis yaitu (1) memahami masalah matematis sebesar $0.35 \quad(8,75 \%)$; (2) merencanakan penyelesaian masalah sebesar $0,10(2,5 \%)$; (3) menyelesaikan masalah sebesar 0,24 (6\%); dan (4) memeriksa kembali sebesar 0,6 (15\%). Hal ini menunjukkan kemampuan pemecahan masalah matematis siswa menggunakan perangkat pembelajaran berbasis pendekatan realistik yang dikembangkan mengalami peningkatan dari uji coba I ke uji coba II.

Tabel 3. Peningkatan Kemampuan Pemecahan Masalah Matematis Berdasarkan Ketuntasan Tujuan Pembelajaran Uji Coba I

\begin{tabular}{|c|c|c|c|c|c|}
\hline \multirow{5}{*}{$\begin{array}{l}\text { Tujuan } \\
\text { Pembelajar } \\
\text { an }\end{array}$} & \multirow{3}{*}{\multicolumn{2}{|c|}{$\begin{array}{l}\text { Memahami } \\
\text { peluang } \\
\text { empirik dan } \\
\text { teoretik suatu } \\
\text { kejadian dari } \\
\text { suatu } \\
\text { percobaan }\end{array}$}} & \multirow{2}{*}{\multicolumn{3}{|c|}{$\begin{array}{l}\text { Menyelesaikan } \\
\text { masalah yang } \\
\text { berkaitan dengan } \\
\text { peluang empirik dan }\end{array}$}} \\
\hline & & & & & \\
\hline & & & \multicolumn{2}{|c|}{$\begin{array}{l}\text { teoretik } \\
\text { kejadian dar } \\
\text { percobaan }\end{array}$} & $\begin{array}{l}\text { suatu } \\
\text { suatu }\end{array}$ \\
\hline & Soal & Soal & Soa & Soal & Soal \\
\hline & 1 & 2 & 15 & 3 & 4 \\
\hline \multirow{2}{*}{ Persentase } & 59,2 & 62,4 & 67 & 75,4 & 74,9 \\
\hline & $\%$ & $\%$ & $\%$ & $\%$ & $\%$ \\
\hline Rata-rata & \multicolumn{2}{|c|}{$62,87 \%$} & \multicolumn{3}{|c|}{$75,15 \%$} \\
\hline
\end{tabular}

$\begin{aligned} & \text { Rata-rata } \\ & \text { Keseluruha } \\ & \text { n }\end{aligned} \quad 69,01 \%$

Dari tabel diatas, diketahui bahwa ketuntasan tujuan pembelajaran siswa pada uji coba I belum mencapai kriteria. Dimana kriterianya adalah $0 \% \leq \mathrm{T}<75 \%$, tujuan pembelajaran belum tercapai, sedangkan 75\% $\leq \mathrm{T}<100 \%$, tujuan pembelajaran tercapai.
Tabel 4. Peningkatan Kemampuan Pemecahan Masalah Matematis Berdasarkan Ketuntasan Tujuan Pembelajaran Uji Coba II

\begin{tabular}{|l|l|l|l|l|c|}
\hline \multirow{3}{*}{ Ketuntas } & Soal & Soal & Soal & Soal & Soal \\
\cline { 2 - 5 } & 1 & 2 & 3 & 4 & 5 \\
\hline
\end{tabular}

an

Tujuan

\begin{tabular}{llllll} 
Pembelaj & $\begin{array}{l}81,1 \\
\text { aran }\end{array}$ & $80 \%$ & $\begin{array}{l}80,3 \\
\%\end{array}$ & $\begin{array}{l}80,8 \\
\%\end{array}$ & $\begin{array}{l}81,6 \\
\%\end{array}$ \\
\hline Rata-rata & \multicolumn{3}{c}{$80,76 \%$} &
\end{tabular}

Kemudian Berdasarkan hasil analisis angket respon siswa pada uji coba II dapat dilihat bahwa hasil persentase dari aspek pertama, persentase siswa yang menyatakan senang terhadap materi pelajaran mencapai $97,3 \%$, siswa yang senang terhadap buku siswa mencapai $97,3 \%$, siswa yang senang terhadap LKPD mencapai $100 \%$, siswa yang senang terhadap suasana belajar di kelas sebanyak 94,6\%, dan siswa yang senang terhadap cara guru dalam mengelola pembelajaran sebanyak $100 \%$.

\section{Self-Confidence}

Pembagian angket sikap self-confidence siswa dilakukan setelah pembelajaran (posttest). Angket sikap self-confidence yang diberikan sebanyak 25 butir pernyataan yang terdiri dari 15 butir pernyataan positif dan 10 butir pernyataan negatif dengan 4 indikator selfconfidence yaitu: (1) Keyakinan/Percaya diri (2) Bertindak mandiri (3) Memiliki Konsep diri yang positif (4) Berani mengemukakan pendapat.

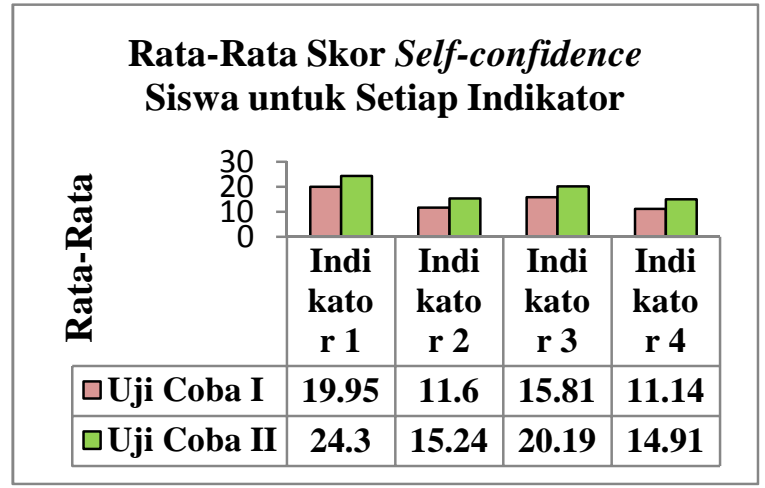

Gambar 1. Angket Self-confidence Uji Coba I dan Uji Coba II

Berdasarkan Gambar di atas dapat disimpulkan bahwa rata-rata hasil angket self-confidence siswa meningkat dari hasil uji coba I ke uji coba II, yaitu pada uji coba I sebesar 58,48, pada uji coba II sebesar 74,6 dan mengalami peningkatan sebesar 16,12. Sedangkan rata-rata skor setiap indikator juga terdapat peningkatan dari uji coba I ke uji coba II.dengan skor maksimal adalah 100. Masing-masing rata-rata skor setiap indikator pada uji coba I yang meningkat ke uji coba II yaitu: (1) Indikator Keyakinan/Percaya diri, dimana pada uji coba I dengan rata-rata sebesar 19,95 sedangkan pada uji coba II dengan rata-rata sebesar 24,3, peningkatan untuk indikator 1 sebesar4,35 point; (2) Indikator Bertindak mandiri, dimana pada uji coba I dengan rata-rata sebesa11,6, sedangkan pada uji coba

Pengembangan Perangkat Pembelajaran Berbasis Pendekatan Realistik untuk Meningkatakan Kemampuan Pemecahan Masalah dan Self Confidence Siswa 


\section{PARADIKMA JURNAL PENDIDIKAN MATEMATIKA}

Vol. 13, No. 2, Desember 2020

II sebesar 15,24, peningkatan untuk indikator 2 sebesar 3,64 point; (3) Indikator Memiliki konsep diri yang positif, dimana pada uji coba I dengan rata-rata sebesar 15,81, sedangkan pada uji coba II sebesar 20,19, peningkatan untuk indikator 3 sebesar 4,38 point dan (4) Indikator Berani mengemukakan pendapat, dimana pada uji coba I dengan rata-rata sebesar 11,14 , sedangkan pada uji coba II sebesar 14,91, peningkatan untuk indikator 4 sebesar 3,77 point. Berdasarkan hasil di atas dapat disimpulkan bahwa self-confidence siswa setelah penerapan perangkat pembelajaran berbasis pendekatan realistik yang dikembangkan meningkat dari uji coba I ke uji coba II.

\section{PEMBAHASAN}

Berdasarkan rumusan masalah penelitian yang diajukan pada bagian sebelumnya, maka berdasarkan data yang diperoleh dari hasil disseminate akan diketahui apakah rumusan masalah yang diajukan telah terjawab atau belum. Hasil analisis data yang diperoleh dari hasil disseminate menunjukkan: (1) adanya peningkatan kemampuan pemecahan masalah matematis siswa melalui pembelajaran mengunakan perangkat pembelajaran berbasis pendekatan realistik yang dikembangkan; (2) perangkat pembelajaran berbasis pendekatan realistik yang dikembangkan efektif ; (3) adanya perbandingan yang signifikan antara siswa yang diberi pembelajaran menggunakan perangkat pembelajaran berbasis pendekatan realistik yang dikembangkan dengan siswa yang diberi pembelajaran biasa.

Pada point ketiga, sejalan dengan teori Bruner, dimana pendekatan realistik cocok dalam kegiatan pembelajaran karena di awal pembelajaran sangat dimungkinkan siswa memanipulasi objek-objek yang ada kaitannya dengan masalah kontekstual yang diberikan guru secara langsung, kemudian pada proses matematisasi vertikal siswa memanipulasi simbol-simbol dalam matematika.

Kemudian berdasarkan penelitian dari Sirait, Aziz (2017) sejalan dengan teori bruner yang berjudul The Realistic of Mathematic Educational Approach (RME) toward the Ability of the Mathematic Connection of Junior High School in Bukhari Muslim Medan. Tujuan dari penelitian ini adalah untuk mengetahui hubungan kemampuan matematis siswa dengan menggunakan pendekatan pendidikan realistik lebih baik daripada pembelajaran konvensional. Hasil penelitian ini menunjukkan bahwa kemampuan koneksi matematis siswa dengan menggunakan pendekatan pendidikan realistik lebih baik daripada pembelajaran biasa.

\section{KESIMPULAN}

1. Terjadi peningkatan kemampuan pemecahan masalah matematis siswa yang diberi pembelajaran dengan menggunakan perangkat yang dikembangkan berbasis pendekatan realistik dibandingkan dengan siswa yang mendapatkan pembelajaran biasa dengan nilai ratarata kelas eksperimen berdasarkan hasil tes kemampuan pemecahan masalah pada uji coba II sebesar 80,86 dengan kelas kontrol sebesar 39,29.

2. Perangkat pembelajaran berbasis pendekatan realistik yang dikembangkan memenuhi kriteria efektif, yaitu: (1) Ketuntasan belajar siswa secara klasikal pada uji coba I mencapai $54,05 \%$, sedangkan pada uji coba II mencapai $86,49 \%$ siswa yang mengikuti THBKPMM berhasil mendapatkan nilai minimal 75. (2) ketuntasan tujuan pembelajaran siswa pada uji coba I mencapai $68,9 \%$, sedangkan pada uji coba II mencapai $80,76 \%$. (3) Respon siswa pada uji coba I mencapai 91,5\%, dan pada uji coba II mencapai $94,54 \%$. Jika dilihat dari kriteria respon siswa, yaitu $80 \%$ siswa memberi respon positif terhadap perangkat pembelajaran yang dikembangkan, maka dapat disimpulkan bahwa respon siswa terhadap perangkat pembelajaran yang dikembangkan adalah positif.

3. Peningkatan self-confidence siswa menggunakan perangkat pembelajaran berbasis pendekatan realistik pada materi peluang adalah rata-rata pencapaian self-confidence siswa pada uji coba I sebesar 58,48 meningkat menjadi 74,6 pada uji coba II.

\section{UCAPAN TERIMA KASIH}

Pada kesempatan ini saya sampaikan penghargaan dan terima kasih yang setinggi-tingginya kepada Direktur dan Asisten Direktur Pascasarjana UNIMED, Kepala Prodi Pendidikan Matematika Pascasarjana UNIMED dan pihak sekolah MTs. YAPNI Lubuk Pakam yang telah memberikan kesempatan kepada saya sehingga penelitian ini dapat diselesaikan sebagaimana yang diharapkan.

\section{REFERENSI}

Asman dan asmaidah. 2017. Pengembangan Perangkat Pembelajaran Matematika Realistik Untuk Membelajarkan Kemampuan Pemecahan Masalah Matematika Siswa Smp. Jurnal "Mosharafa", Volume 6, Nomor 3. p-ISSN: 2086-4280; e-ISSN: 2527-8827.

Hasratuddin. 2015. Mengapa Harus Belajar Matematika? Medan: Perdana Publishing.

Iswidharmanjaya, D. 2004. Satu hari menjadi lebih percaya diri. Jakarta : PT. Elex. Media Komputindo.

Jacinta F. Rini. 2002, Psikologi Masalah Stres, Jurnal Repistory Univetsitas Sumatera Utara. Lutfiyah. 2011, Analisi.

Lauster, P. 1978. The Personality Test. London : Pan Books.

Lauster, Peter. 2002. Tes Kepribadian. Jakarta: Bumi Aksara.

Lestari, Kurnia Eka dan M. Ridwan Yudhanegara. 2015. Penelitian Pendidikan Matematika. Bandung: PT. Refika Aditama.

Maulidya, S.S., Surya, E., Syahputra, E. 2017. The Development Of Mathematic Teaching Material Through Realistic Mathematics Education To Increase Mathematical Problem Solving Of Junior High School Students. International Journal Of Advance Research And Innovative Ideas In Education, Vol-3 Issue-2.

Pengembangan Perangkat Pembelajaran Berbasis Pendekatan Realistik untuk Meningkatakan Kemampuan Pemecahan Masalah dan Self Confidence Siswa 
Nieeven, N \& Plomp, T. 2007. An introduction to educational design research netherlands Institude for Curriculum Development.

Nelissen, J.M.C. (2005). Thinking Skill in realistics mathematics. Jurnal Pendidikan Matematika Volume 4. No.2 Desember 201033 Jmc_nelissen :Journal PME. Vol 2 p 108-119 2005.

Ruseffendi, E. T. (2005). Dasar-dasar Penelitian Pendidikan dan Bidang Non Eksakta Lainnya. Bandung: Tarsito.

Romauli, M. (2013). Pengaruh Pembelajaran Matematika Realistik dan Berpikir Logis Terhadap Hasil Belajar Matematika Siswa SD Bharlind School Medan. Jurnal Tematik, 3(12), 1979-0633.

Siregar, K. S., Syahputra, E. 2019. Pengembangan Lembar Keja Peserta Didik Berbasis Realistic Mathematic Education Terhadap Kemampuan Pemecahan Masalah Matematis Siswa. https://www.researchgate.net/publication/333403150.

Suparno, P. 2001. Filsafat Konstruktivisme dalam Pendidikan. Yogyakarta: Kanisius.

Undang-undang Dasar Negara Republik Indonesia Tahun 1945.

Van den Heuvel-Panhuizen. 1998. Realistic Mathematics Education Work in Progress. Norway : Faculty of Mathematics and Science. [Online].Tersedia : http://www.fisme.science.uu.nl/staff/marjah/document s/Marja_Work-in progress.pdf. (15 April 2015).

Veloo, A., A, R. M., Ahmad, H. 2015. Effect of Realistic Mathematics Education Approach Among Pubic Secondary School Students In Riau, Indonesia .Australian Journal of Basic and Applied Sciences, $9(28)$.

Wardhani, Sri dkk. 2010. Pembelajaran Kemampuan Pemecahan Masalah Matematika di SD. Yogyakarta: PPPPTK.

Yosmarniati, dkk. 2014. Upaya Meningkatkan Kemampuan Komunikasi Matematika Siswa Melalui Pendekatan Pendidikan Matematika Realistik. Jurnal Pendidikan Matematika Part 3, 1 (1), hlm 64-69.

Zakaria, E., Syamaun, M. 2017. The Effect of Realistic Mathematics Education Approach on Students' Achievement And Attitudes Towards Mathematics. Mathematics Education Trends and Research 2017 No.1 (2017) 32-40, Volume 2017, Issue 1, hlm 32.

Zubainur, C. M., Veloo, A., Khalid, R. 2014. The Effect of Realistics Mathematics Education Approach on Students' Achievement And Attitudes Towards Mathematics. International Conference on Mathematics, Engineering and Industrial Applications AIP Conf. Proc. 1660, 050077-1-050077-5. 